Annals of Warsaw University of Life Sciences - SGGW

Land Reclamation No 48 (4), 2016: 299-312

(Ann. Warsaw Univ. Life Sci. - SGGW, Land Reclam. 48 (4), 2016)

\title{
Implementation of ecological network in existing conditions of municipal spatial management
}

\author{
AGATA PAWŁAT-ZAWRZYKRAJ, KONRAD PODAWCA \\ Department of Civil Engineering, Warsaw University of Life Sciences - SGGW
}

\begin{abstract}
Implementation of ecological network in existing conditions of municipal spatial management. Contemporary socio-economic development requires a rational and sustainable land management. The pressure for urbanization and building development, existing infrastructural barriers and creation of the new ones, contribute to fragmentation of landscape and thus increase isolation of biologically active areas. Idea of ecological network as a tool for maintaining ecological connectivity is not new and has broad theoretical bases, but implementation of this concept in real-life scenarios is very challenging. The article presents existing formal and legal possibilities of implementing ecological networks, enacted as a part of municipal spatial policy. Differentiated approach to implementation of the idea of ecological connectivity is presented on the example of two suburban municipalities Piaseczno and Góra Kalwaria. Ecological network and especially ecological corridors in these areas have varied status of nature conservation and development of investments is implemented either in accordance with local spatial development plans or, in case of lack of the plans, in accordance with development conditions decision. Analysis of changes in spatial development of the municipalities was used to identify risk areas of losing the ecological connectivity.
\end{abstract}

Key words: ecological corridors, spatial planning, land use

\section{INTRODUCTION}

Creating ecological network as a way to counteract natural degradation caused by the fragmentation of the landscape has a long history. There is a broad theoretical basis in the field of the network structure and way of designation of its particular components. At the present time the biggest challenge seems to be the implementation of the network in practice. The ecological network should be implemented primarily by appropriate shaping the functional and spatial structure of the area set in the spatial planning policy and then introduced to the investment process. In the current legal framework there are no precise obligations for a municipality to include the ecological network in the spatial planning process (Kistowski and Pchałek 2009, Bernatek 2011, Pchałek et al. 2011, The National Spatial Development Concept 2012).

The network as a hierarchical structure should be comprehensively implemented at all levels of spatial planning (Żarska 2006). On the national level the most important document is the National Spatial Development Concept (M.P. 2012, poz. 252), having the rank of strategic guidelines for long-term implementation. The document currently in force was adopted in 2011 and includes a vision of the spatial development of 
Poland until 2030. The document contains plans for integration of activities in the field of functioning of a coherent national ecological network as a basis for protection of the most valuable natural and landscape resources.

Next level in the hierarchy of ecological network is the regional level in which the plans of spatial development for a voivodeship (PZPW) are developed. Such plans include guidelines from the National Spatial Development Concept and resulting from the principle of maintaining continuity of spatial structures between neighbouring voivodeships, but mainly contain objectives and directions corresponding to the specific character of the region (problems, needs, resources). The amendment to the Act on spatial planning and development introduced in 2016, created obligation to perform landscape audits for voivodeships (Art. 38a published in Dz.U. of 2016, poz. 778 , as amended). By law, the audits should be updated at least once every 20 years. The results of the audit are to be the basis for verification of existing boundaries of conservation areas in case of decrease in value of landscape. It can also provide indications to extend the protection to new areas. Currently criteria for assessment and evaluation of landscape for the audit are not yet established. Therefore, it is not certain if the issue of land fragmentation will be addressed. However, the landscape audit will be another document that is taken into account in preparation of Plans of Spatial Development for a Voivodeship.
The studies enacted for individual voivodeships formulate general principles for the protection of ecological continuity. Unfortunately under current legislation, these principles do not have to be respected in spatial planning at the local level (Bernatek 2011). The key level for the implementation of ecological network is the local level. Introduction of discontinuities in the network at the municipal level will result in disturbance in the functioning of corridors at higher level (Pchałek et al. 2011). The basis of local spatial policy is formulated in the Study of conditions and directions of the spatial management for a municipality (SUiKZPG - hereinafter as the Study). The Study presents the concept of spatial development of the municipality. The concept is created under guidelines specified in the higher order documents (national and regional) taking into account local conditions, including environmental ones (resources, threats, conflicts, needs). Many municipalities in their enacted Studies, in the part concerning directions of development, determine the ecological network and establish land-use principles to support it (preservation of biological function of areas; restriction of extension of land for construction purposes; concentration of built-up areas in selected locations to prevent its dispersion; parameters, features and indicators governing building development to maintain its low intensity etc.). At the same time it should be emphasized that in many ex- 
isting studies ecological network has not been determined. This is not equivalent to a lack of concern for the preservation of ecological connectivity, but in many cases it may indicate a lower rank of the issue in development priorities of a municipality This is facilitated by the lack of a formal requirement to include an ecological network in the Study. The study regulations are not directly binding to the investors, but they are mandatory for development of local spatial development plans (hereinafter as the local plans; Art. 9, ust. 4, Dz.U. 2016, poz. 778). Properly formulated principles of development, that take into account requirements of maintenance and functioning of ecological network, are an essential tool for implementation of the concept. In areas for which there is no valid local spatial plan, development of the land is regulated by an administrative decision on localization of a public purpose investment project (ulicp) or decision on land development conditions (wz) (Art. 4, ust. 2, Dz.U. 2016, poz. 778 ). This procedure generally applies to small areas and is governed by a number of conditions. However, it does not guarantee protection of areas located within a designated ecological network against excessive, often dispersed housing development and the creation of new spatial barriers. Especially that the number of housing investments carried out on procuring administrative decisions (when there is no local spatial plan) is still very high and can cover approx. $40-50 \%$ of all this type of construction sites. The percentage of negative decisions was low. In 2013 it was $1 \%$ for public purpose investments and $4 \%$ in the case of private investments (Śleszyński et al. 2015).

Ecological network consists of several elements, such as (Bennett 1998, Richling and Solon 1998, Jongman and Pungetti 2004, Worboys et al. 2010).

- core areas (patches, biocentres) - large areas with the highest naturalness, biodiversity and ecological stability; usually partially or entirely under some kind of nature conservation;

- corridors (routes or ecological strings) - natural, semi-natural and even anthropogenic areas (linear or nonlinear, continuous or discontinuous - "stepping stones") enable maintaining ecological connectivity, including migration, dispersion and genetic exchange of species between core areas;

- buffer zones - surround core areas and corridors to protect them against potential external threats.

In this article the ecological corridors are considered a key element in implementation of environmental connectivity in highly anthropogenic municipalities.

The aim of the research is:

- to evaluate spatial policy of the analysed municipalities in terms of sustaining spatial and landscape continuity of ecological corridors indicated in the Studies;

- to present the relation between maintenance of the functional and spatial 
structure enabling ecological connectivity and implementation of the concept on the basis of the enacted local spatial development plan.

\section{MATERIAL AND METHODS}

Two rural-urban neighbouring municipalities Piaseczno and Góra Kalwaria were selected for the investigation. The first one directly borders Warsaw from the south, the other is located at a distance of approx. $35 \mathrm{~km}$ from the border of the city. The economic development of the municipalities is highly influenced by the strength of external and local factors. The most important external factors are proximity to Warsaw and supra-local roads. Internal factors are related to local production and agricultural (fruits and vegetables) potentials, as well as recreational values. The direct vicinity of the municipalities makes it possible to analyse the continuity of natural links in larger spatial dimension, not only within the administrative units but also including the "cross-border" links between them.

The bases of the research were the concepts of ecological network for both municipalities, enacted in their study of the spatial management conditions and directions. The analysis included changes in the planned network structure (especially ecological corridors), that were adopted in several amendments to spatial policy of the municipalities: the Study for the Piaseczno municipality (Giedych et al. 2006, Świetlik et al. 2014), the Study for the municipality Góra Kalwaria (Zarębska-Rolke et al.
2000, Solarek et al. 2006, 2011, 2013). In the paper, the corridors are defined in landscape approach (physiographic, geographic) in which the corridors are treated simply as physical structures that ensure connectivity (landscape coherence) (Pchałek et al. 2011).

Subsequent stages of the research included analysis of:

- conservation status of areas located within ecological corridors under the Nature Conservation Act (Dz.U. 2015 poz. 1651, as amended) and secondary legislation, based on data obtained from The General Directorate for Environmental Protection (www.gdos.gov.pl, http://www.gdos. gov.pl/dane-i-metadane, http://geoserwis.gdos.gov.pl/mapy);

- areas of ecological corridors covered by local plans, which is a key factor for the management of the ecological network in the analysed municipalities. Data source: spatial information system (SIP) for Góra Kalwaria municipality and Piaseczno municipality accessible at: http://mpzp. gorakalwaria.pl, www.piaseczno.eu, interactive map of local spatial development plans for Piaseczno municipality (http://piaseczno.eu/000 plan/000_plan.swf);

- land development principles contained in local plans in terms of maintaining continuity of ecological connectivity, including: scope, level of details, type of rules and spatial development requirements, to clarify the concept of the ecological system 
defined in the Study for the analysed municipalities. Data source: SIP changes in the spatial development of ecological corridors, particularly including creation of new spatial barriers (spread of built up areas, fences, roads), based on analysis of orthophoto maps provided by Geoportal (geoportal.gov.pl) and Google Earth (http://www.google.com/earth) showing the state of land development (land cover) during the years 2002-2015, supplemented by the outcome of additional on-site inspection, carried out in June and September 2015 .
Spatial analysis and final maps were prepared by means of the ArcMap 10.3.1 application being part of the ArcGIS software.

The survey results allowed to identify areas where changes in spatial development can lead to marginalization or loss of significance of an area as an ecological corridor.

\section{RESEARCH AREA}

In the structure of ecological network in Piaseczno municipality (Fig.), enacted in the current Study (Świetlik et al. 2014), one can indicate the following components:

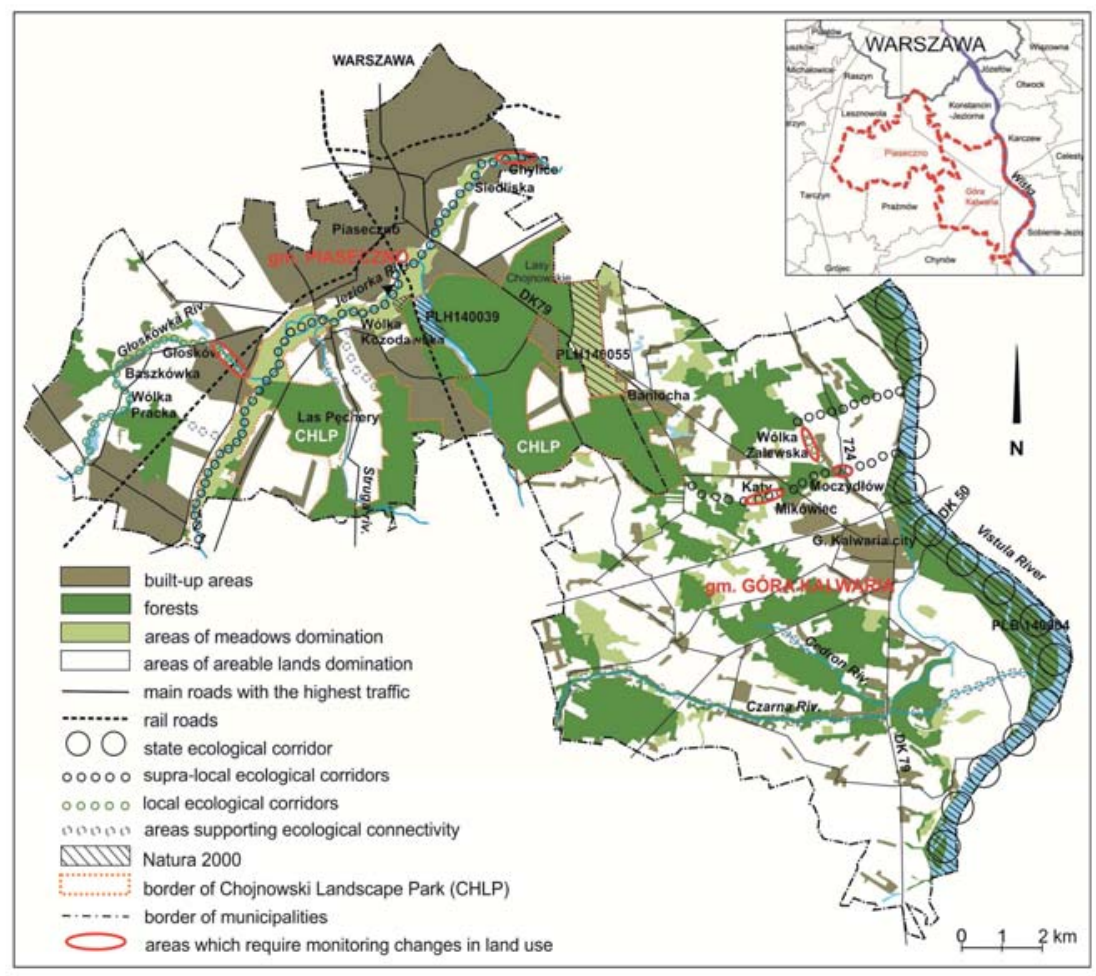

FIGURE. Ecological network in Piaseczno and Góra Kalwaria municipalities according to the Study 
- core areas: (1) regional significancelarge forest complexes located in central, eastern and southern parts of the municipality (mostly within borders of the Chojnowski Landscape Park - ChPK), spatially connected with the Nature 2000 sites (Łąki Soleckie PLH140055 and Stawy in Żabieniec PLH140039); (2) local significance - smaller forest areas in south-western part of the municipality;

- ecological corridors: (1) regional significance - the valley of the Jeziorka river with permanent pasture, woodlots, shrubs and water reservoirs; it connects the regional core area with national corridor along the valley of Vistula river; in large part, i.e. from Jazgrzew up the river - within the ChPK, the rest - within Warsaw Area of Protected Landscape - WOChK; (3) local significance - the valley of Głoskówka river, connecting forest areas in the south-western part of the commune with the corridor along Jeziorka river; under protection of WOChK; (3) supporting areas - the areas indicated to strengthen and support the functioning of ecological network; designated for the development of: agriculture, forestry, landscaping, recreation and leisure and extensive residential buildings; in most cases, the location and shape of these areas enables the indirect communication between the elements of the network; the spatial range is approximate (general).
In the directions of spatial management contained in the Study, the area of the ecological network of the municipality (including supporting areas and corridors) was determined to be excluded from construction purposes.

The concept of the ecological network in the Study for Góra Kalwaria municipality (Zarębska-Rolke et al. 2000, Solarek et al. 2006, 2011, 2013) was subject to several modifications in terms of theoretical bases, as well as in the very structure (Pawłat-Zawrzykraj and Brzank 2013). In the current Study (Solarek et al. 2013) the following elements of ecological network can be indicated (Fig.):

- core areas of regional significance - forest complexes located in in the north-west part of the municipality (Chojnowski Forests, within area of Chojnowski Landscape Park) directly neighbouring Łąki Soleckie, a Nature 2000 site;

- ecological corridors: (1) state significance - the valley of Vistula river and its old river bed, along the eastern border of the municipality; oriented north-south; part of the area under Bird Special Protection Area PLB 140004, the remaining area within WOChK; (2) supra-local significance - two "forest" corridors discontinuous in structure (stepping stones) located in the northern part of the municipality, oriented east-west, connecting large Chojnowski Forests with the valley of Vistula river, the 
corridors are not subject to any protection of the natural environment; (3) spatial management directions in the Study also provide for "the designation of continuous network of biologically active areas along the river valleys associated with urban green areas, forests and other open areas" (Solarek 2013); natural connection along the Cedron river valley (currently unprotected) and the valley of Czarna river, both east-west oriented, connecting forest areas located in the south-western part of the municipality with the Vistula river valley (the valley of Czarna river under protection of WOChK).

The main elements of the network, especially including location of two "forest" corridors, were approx. designated on the map of spatial management directions. The layout of the corridors along the river valleys was not established, although it was determined in the ecophysiographic study (Fic 2005, Chojnacki 2012). There is no graphical distinction that visualizes significance of particular elements of the network, especially lack of delimitation for the borders of the corridors which results in flexible interpretation of their parameters.

The preliminary analysis of factors influencing development of the studied areas (investment attractiveness, existing or planned spatial barriers - mostly roads) enabled to indicate the following areas that require monitoring of spatial development:
- in Piaseczno municipality: (1) part of ecological corridor along the valley of Jeziorka river in the boundaries of the Piaseczno town through Chylice village up to the eastern border of the municipality; according to the division of the municipality for spatial policy zones, it belongs to the zone of intensive multifunctional development; (2) ecological corridor along the valley of Głoskówka river;

- in Góra Kalwaria municipality "forest" corridors in northern part of the municipality - one located near Wólka Zalewska village, the second one between villages Kąty, Mikówiec and Moczydłów (Fig.).

\section{RESULTS}

The majority of state-significant ecological corridors (Vistula river valley) and some of the regional ones (Jeziorka river valley) are under legal protection. The law sets standard operating procedures at the planning stage, as well as at the initial stages of the investment process. According to Bernatek (2011), approx. $60 \%$ of highly significant ecological corridors areas overlap legally protected areas $(35 \%$ are protected landscape areas, $21 \%$ - landscape parks, $4 \%$ - national parks, $1 \%$ - nature reserves). Usually, ecological connections of lower rank are unprotected. This also applies to "forest" corridors in Góra Kalwaria municipality. Local corridors designated along river valleys (Głoskówka river in Piaseczno municipality, Czarna and Cedron 
rivers in Góra Kalwaria municipality) are situated in Warsaw Protected Landscape Area. It is a form of nature conservation covering large areas of municipalities around Warsaw. According to $\S$ 1.1 of Regulation 3 of the Mazowiecki Voivode of 13 February 2007 concerning the Warsaw Protected Landscape Area (Dz.U. Woj. Maz. 2007, nr 42, poz. 870 , as amended), "areas protected because of distinguishing landscape, various ecosystems, valuable because of their ability to fulfill the needs of tourism and recreation, as well as their function of ecological corridors in the area", are protected by law. An important tool for implementation of this protection is $\S 6.1 .8$ that prohibits "locating constructions within 20 meters from the banks of rivers, lakes and other reservoirs, with the exception of water facilities for conducting rational agriculture, forestry and fishing". This is the rule that guarantees the preservation of continuity of ecological corridors along riverbeds, both in case of preparation of local spatial development plan drafts concerning such areas, as well as localization procedures If such plan is not available. In the literature, it is assumed that the corridor should be as broad as possible, but within certain limits (Liro and Szacki 1993, Żarska 2006). Research confirms that every animal species in specific ecological conditions has its optimum width of the corridor because of the efficiency of dispersion and migration (Pchałek et al. 2011). Perzanowska (2005) recommends a minimum width of unfenced connections and passages between buildings to be between 50 and $100 \mathrm{~m}$.

Assuming that the function of local ecological corridor assigned in the Study for a municipality does not guarantee ecological connectivity, coverage of local plans for area of corridors and their nearest neighbourhood was analysed. It is a very important issue in case of areas which are not subject to any protection of the natural environment. Piaseczno municipality is characterized by the very high coverage of local plans for rural areas (most of the areas except forests and those under water) as well as the whole area of Piaseczno town (a total of 131 plans covering $51 \%$ of the municipality area, as at April 2016) - Table 1. The level of advancement of planning and design works for the analyzed ecological corridors is diversified but in some cases lack of spatial continuity can be observed (Table 2). For example, the local corridor along the valley of Głoskówka river is partly surrounded by agricultural area, but in the large part - by areas of existing and planned residential villages Głosków, Baszkówka and Wólka Pracka. In agricultural areas there are no local plans in force, whereas the areas with dominating residential function are covered by plans. The ecological corridor itself is excluded from the plan, leaving a narrow strip of land having no plan at all. Part of the lower stream is covered by the plan - areas of surface waters and a narrow strip of natural greenery were indicated. Ecologi- 
TABLE 1. Coverage of the analysed municipalities with local spatial development plans and natural conservation

\begin{tabular}{|l|c|c|c|}
\hline Indicators & Unit & Piaseczno & Góra Kalwaria \\
\hline The area of a municipality & $\mathrm{km}^{2}$ & 128.12 & 143.9 \\
\hline \multirow{2}{*}{$\begin{array}{l}\text { The area of a municipality covered with local spatial } \\
\text { development plans }\end{array}$} & $\mathrm{km}^{2}$ & 65.34 & 34.02 \\
\cline { 2 - 4 } & $\%$ & 50.99 & 23.62 \\
\hline The area of municipality under natural conservation & $\mathrm{km}^{2}$ & 90.1 & 89.02 \\
\hline $\begin{array}{l}\text { The share of natural conservation in total area } \\
\text { of a municipality }\end{array}$ & $\%$ & 70.32 & 61.86 \\
\hline
\end{tabular}

TABLE 2. Coverage of the analysed ecological corridors with local spatial development plans and natural conservation

\begin{tabular}{|l|c|c|c|c|}
\hline \multirow{2}{*}{ Indicators } & \multirow{2}{*}{ Unit } & $\begin{array}{c}\text { Piaseczno } \\
\text { supra-local, } \\
\text { local and } \\
\text { supporting } \\
\text { corridors }\end{array}$ & $\begin{array}{c}\text { supra-local, } \\
\text { local and } \\
\text { supporting } \\
\text { corridors }\end{array}$ & $\begin{array}{c}\text { including also } \\
\text { corridor in } \\
\text { the valley of } \\
\text { Vistula river }\end{array}$ \\
\hline The area of ecological corridors & $\mathrm{km}^{2}$ & 9.58 & 6.06 & 20.26 \\
\hline The share of ecological corridors & $\%$ & 7.48 & 4.21 & 14.1 \\
\hline in total area of a municipality & $\%$ & 2.36 & 0.62 & 0.62 \\
\hline $\begin{array}{l}\text { The area of ecological corridors } \\
\text { covered with local spatial development } \\
\text { plans }\end{array}$ & $\mathrm{km}^{2}$ & 24 & 10.24 & 3.06 \\
\cline { 3 - 5 } $\begin{array}{l}\text { The area of ecological corridors } \\
\text { under natural conservation }\end{array}$ & $\mathrm{km}^{2}$ & 9.48 & 4.5 & 18.69 \\
\cline { 3 - 6 } $\begin{array}{l}\text { The area of ecological corridors which } \\
\text { is not subject neither to any protection } \\
\text { of the natural environment nor covered } \\
\text { with local spatial development plans }\end{array}$ & $\mathrm{km}^{2}$ & 98.95 & 75 & 92.26 \\
\cline { 3 - 6 } & $\%$ & - & 1.28 & 1.28 \\
\hline
\end{tabular}

cal corridor along the valley of Jeziorka river surrounded by highly urbanized villages Wólka Kozodawska, Siedliska, Chylice and town Piaseczno, as well as so called "supporting area" along the valley of Struga river (connecting forest of CHLP with Jeziorka river); not yet legally protected. are fully covered by local plans. Development that combines natural functions with unobtrusive public services, such as: permanent pastures with trees, green areas, services dealing with sports and recreation, is mostly al- lowed in local plans that cover Jeziorka valley.

In Góra Kalwaria municipality part of the area covered by local development plans is much smaller (117 plans - approx. $24 \%$ of the municipal area) - Table 1 . The majority of studies relate to areas located in the northern part of the municipality (especially along the National Road 79), regarded as a priority zone for development from the socioeconomic point of view. In the remaining part of the municipality, areas under 
existing local plans are scattered and in most cases already urbanized. Very often work on plans projects are undertaken at the request of residents and landowners interested in change of land use designation to non-agricultural purposes. "Forest" corridors located in the northern part of the municipality are not covered by local plans in force. An example of a low-prioritization of local ecological corridors in designation for plan making is a corridor located between villages Kąty, Mikówiec and Moczydłów (Fig.). In the Study the area within the ecological corridor is designated for afforestation or agricultural use and surrounded from the north and south by single-family housing, area of service and production facilities, warehouses and storage facilities. The areas of growing urbanization are covered with local plans while the areas defined as the ecological corridor are excluded from them. This kind of strategy allows to establish clear regulations for the spatial development of the areas surrounding the corridor, but does not guarantee preservation of natural links identified in the Study. Local corridor in the valley of Czarna river is covered by local plans only in parts running through areas of existing villages. The plans provide ecological connectivity, keeping narrow strip of green areas, at a minimum level (except for road barriers - DK 79). Local corridor in the valley of Cedron river is not covered by local plans, but is protected from construction development efforts by its location inside the Warsaw Protected Landscape Area.

Analysis of designation of areas in the current local plans in Piaseczno and Góra Kalwaria municipalities confirms the diagnosis of Śleszyński (2015) that in the current documentation, land intended for building and constructions is the majority. This pattern is partly due to the fact that local plans are primarily established in order to organize the settlement and urbanization, but it also indicates the pressure of investment and oversupply of land dedicated for investment purposes.

Changes in spatial development of ecological corridors observed during 2002-2015 show a various urbanization rate for the considered areas: more intensive in northern parts of the municipalities that are strongly associated with Warsaw, lower or weak in the south, where the importance of agricultural and fruit production activities remain constantly high. In the current formal and legal conditions, the least effective is to control changes in spatial development of ecological corridors, especially for non-agricultural purposes, that are not only excluded from regulations of local plans, but also deprived protection of formal nature conservation. An example of this kind of unfavourable changes in the analysed municipalities is the "forest" ecological corridor located between villages Kąty, Mikówiec and Moczydłów in Góra Kalwaria municipality. The corridor has a width varying 
from 80 to $890 \mathrm{~m}$. It can be both habitat, as well as path of migration for small mammals and large predators. None of the planned in the Study afforestation has been conducted. Only the natural forest succession is visible in some places. At the same time the area of single-family housing grows, spreading as narrow strips perpendicular to the course of the corridor, causing the latter to lose ground. Lack of the local plan for this area makes it practically impossible to limit further housing development and prevent losing ecological connectivity.

\section{CONCLUSIONS}

1. Enactment of local spatial development plan, having the rank of local law, that establishes functional and spatial structure of the area and detailed rules governing development and management of land, is potentially the most effective tool for implementing ecological network at municipal level. Nature conservation is another significant tool used to prevent ecological corridors from building spread, especially when new constructions are being developed in areas not covered with local plans. Criteria for eligibility of areas to be designated for local plans should be extended, to strengthen the priorities for nature protection, particularly to maintain ecological connectivity and balance them with socio-economic needs. In designation of ecological network area to be included in local plan, it is very important to take into account land not covered by any kind of formal nature conservation.

2. Analysis of coverage of local plans for area of corridors and changes in spatial development of ecological corridors in Piaseczno and Góra Kalwaria municipalities indicate, that implementation of ecological network is more active and more effective in the former.

3. Major factor supporting the ecological connectivity of the Piaseczno municipality is the fact, that the ecological network is mostly determined in those parts that are already covered with some formal nature conservation ( $98 \%$ of the corridors' area). Furthermore, coverage of the corridors with local plans is rather satisfactory $(25 \%)$ - mostly in sections located in highly urbanizing parts of the municipality (Wólka Kozodawska, Piaseczno, Siedliska, Chylice).

4. Ecological corridors in Góra Kalwaria municipality are subject of local plans to a small extent $(10 \%)$. The share of ecological corridors covered with nature conservation is rather high $(75 \%)$, but it mostly concerns ecological connections of the lowest rank, located in central and southern (agricultural) parts along river valleys. Exactly $21 \%$ of ecological corridors area is not included in local plans nor natural conservation - they are located in northern, intensively urbanising parts of the 
municipality (the corridors: Kąty-Mikówiec-Moczydłów and Wólka Zalewska-Moczydłów). Increasingly burdensome road barriers and mostly the spread of residential housing at the expense of planed forestations (in the Study) gradually reduce and in perspective, even prevent ecological connection designated in form of ecological corridors from existing.

\section{REFERENCES}

BENNETT A.F., 1998: Linkages in the Landscape. The Role of Corridors and Connectivity in Wildlife Conservation. Gland, Switzerland and Cambridge, IUCN, UK.

BERNATEK A. 2011: Ocena wdrażania koncepcji korytarzy ekologicznych do planów zagospodarowania przestrzennego województw [Evaluation of the implementation of concept of ecological corridors in plans of spatial development for Voivodship]. WWF Polska, Agencja Wydawnicza EkoPress, Warszawa.

CHOJNACKI G. 2012: Opracowanie ekofizjograficzne podstawowe dla obszaru gminy Góra Kalwaria - aktualizacja [Ecophysiographic study for Góra Kalwaria municipality - update]. Kanon [unpublished].

Rozporządzenie Nr 3 Wojewody Mazowieckiego z dnia 13 lutego 2007 r. w sprawie Warszawskiego Obszaru Chronionego Krajobrazu [Regulation 3 of the Mazowiecki Voivod of 13 February 2007 concerning the Warsaw Protected Landscape Area]. Dz.U. Woj. Maz. $2007 \mathrm{nr}$ 42, poz. 870, z późn. zm.

FIC M. 2005: Opracowanie ekofizjograficzne dla terenu gminy Góra Kalwaria [Ecophysiographic study for Góra Kalwaria municipality]. AQUAGEO [unpublished].

GIEDYCH J., GIEDYCH R., WISZNIEWSKA A., PARYS S. 2006: Studium uwarunkowań i kierunków zagospodarowania przestrzennego miasta i gminy Piaseczno [Study of conditions and directions of the spatial management for Piaseczno municipality]. ARCADIS EKOKONREM sp. z.o.o. [unpublished].
JONGMAN R., PUNGETTI G. 2004: Ecological Networks and Greeneways - Concept, Design, Implementation. Cambridge University Press, Cambridge.

KISTOWSKI M., PCHAŁEK M. 2009: Natura 2000 - w planowaniu przestrzennym - rola korytarzy ekologicznych [Natura 2000 - in the spatial planning - the role of ecological corridors]. Ministerstwo Środowiska, Warszawa.

LIRO A., SZACKI J. 1993: Korytarz ekologiczny - przegląd problematyki [Ecological corridor - an overview of the issue]. Czlowiek $i$ Środowisko 17, 4, 299-312.

PAWŁAT-ZAWRZYKRAJ A., BRZANK M. 2013: Zachowanie ciągłości polityki przestrzennej gminy w zakresie tworzenia sieci ekologicznej na przykładzie Gminy Góra Kalwaria [Continuity of spatial management of a commune in terms of building up its ecological network on the example of the Commune Góra Kalwaria]. Przeglą Naukowy Inżynieria i Kształtowanie Środowiska 22 (4), 402-412.

PCHAŁEK M., KUPCZYK P., MATYJASIAK P., JUCHNIK A., 2011: Efektywność ochrony korytarzy ekologicznych. Koncepcja zmian legislacyjnych [The effectiveness of the protection of ecological corridors. The concept of legislative changes]. WWF Polska, Agencja Wydawnicza EkoPress, Warszawa.

PERZANOWSKA J. 2005: Korytarze ekologiczne $\mathrm{w}$ Małopolsce [Ecological corridors in Małopolska]. Instytut Nauk o Środowisku UJ, Instytut Ochrony Przyrody PAN, Kraków.

RICHLING A., SOLON J. 1998: Ekologia Krajobrazu [Landscape ecology]. PWN, Warszawa.

ŚLESZYŃSKI P., KOMORNICKI T., DERĘGOWSKA A., ZIELIŃSKA B., 2015: Analiza stanu i uwarunkowań prac planistycznych w gminach 2013 roku [Analysis of the status and conditions of planning works in the municipalities for the year 2013]. PAN Instytut Geografii i Przestrzennego Zagospodarowania, Warszawa.

SOLAREK K. et al. 2006, 2011, 2013: Studium uwarunkowań i kierunków zagospodarowania przestrzennego miasta i gminy Góra Kalwaria [Study of conditions and directions of the spatial management for Góra Kalwaria muni- 
cipality]. SOL-AR Pracowania Architektury i Urbanistyki Warszawa, [unpublished].

ŚWIETLIK M. et al. 2014: Studium uwarunkowań i kierunków zagospodarowania przestrzennego miasta i gminy Piaseczno [Study of conditions and directions of the spatial management for Piaseczno municipality]. Biuro Planowania Rozwoju Warszawy S.A., Warszawa [unpublished].

Uchwała nr 239 Rady Ministrów z dnia 13 grudnia 2011 r. w sprawie przyjęcia Koncepcji Przestrzennego Zagospodarowania Kraju 2030 [The National Spatial Development Concept]. M.P. 2012, poz. 252.

Ustawa z dnia 16 kwietnia 2004 r. o ochronie przyrody [The Nature Conservation Act]. Dz.U. 2015, poz. 1651, z późn. zm.

Ustawa z dnia 27 marca 2003 r. o planowaniu i zagospodarowaniu przestrzennym [The Act on spatial planning and development]. Dz.U. 2016, poz. 778 .

WORBOYS G., FRANCIS W., LOCKWOOD M. 2010: Connectivity Conservation Management - A Global Guide, Earthscan, London.

ŻARSKA B. 2006: Modele ekologiczno-przestrzenne i zasady kształtowania krajobrazu gmin wiejskich [Environmental and spatial models and principles of shaping the landscape of rural municipalities]. Wydawnictwo SGGW, Warszawa.

Streszczenie: Możliwości realizacji sieci ekologicznej $w$ istniejacych uwarunkowaniach gospodarki przestrzennej $w$ gminie. Presja zabudowy, powstające nowe bariery infrastrukturalne oraz rosnąca ranga już istniejących przyczyniają się do fragmentacji krajobrazu, a co za tym idzie do postępującej izolacji obszarów biologicznie czynnych. Idea sieci ekologicznej jako narzędzia służącego utrzymaniu łączności przyrodniczej nie jest nowa i ma szerokie podstawy teoretyczne. Trudność stanowi realizacja tej koncepcji w praktyce. Jako przykład zróżnicowanego podejścia do realizacji idei ciągłości przyrodniczej posłużyły obszary dwóch sąsiadujących ze sobą podwarszawskich gmin: Piaseczno i Góra Kalwaria. Podstawą badań były koncepcje systemu przyrodniczego obu gmin uchwalone w studium uwarunkowań i kierunków zagospodarowania przestrzennego. Za kluczowy element sieci przyjęto korytarze, definiowane w ujęciu krajobrazowym jako struktury fizyczne zapewniające łączność ekologiczną. Wychodząc z założenia, że kwalifikacja obszaru do pełnienia roli korytarza ekologicznego zawarta w studium nie jest gwarantem utrzymania ciągłości przyrodniczej, przeanalizowano status ochrony przyrodniczej i status planistyczny korytarzy (czy istnieją dla nich aktualne plany miejscowe), ustalenia planów miejscowych istotnych dla utrzymania sieci oraz zmiany w zagospodarowaniu, szczególnie obejmujące powstawanie nowych barier przestrzennych (zabudowa, ogrodzenia, drogi). Analiza zmian w zagospodarowaniu obszarów korytarzy rozpatrywanych gmin wskazuje na większą skuteczność wdrażania koncepcji sieci ekologicznej w gminie Piaseczno. Jest to wypadkowa dwóch czynników: objęcia ochroną przyrodniczą niemal całego obszaru korytarzy (98\%) oraz objęcia ustaleniami planów miejscowych znacznych obszarów $(25 \%$ - w tym w większości na obszarach poddanych silnej antropopresji), co umożliwiło doprecyzowanie struktury przestrzennej i zasad zagospodarowania. W gminie Góra Kalwaria udział powierzchni korytarzy objętych ochroną przyrodniczą jest dość znaczny (75\%), ale dotyczy przede wszystkim powiązań najniższej rangi, zlokalizowanych $\mathrm{w}$ centralnej i południowej (rolniczej) części gminy wzdłuż dolin rzecznych. Obszary korytarzy nie objęte ochroną przyrodniczą oraz ustaleniami planów miejscowych $(21 \%$ ogólnej powierzchni korytarzy) są zlokalizowane w północnej, najbardziej atrakcyjnej inwestycyjnie części gminy. Analiza zmian w zagospodarowaniu tych obszarów wskazuje na stopniowe rozprzestrzenianie się zabudowy, w krótkiej perspektywie prowadzące do zaniku łączności przyrodniczej (korytarze: Kąty-Mikówiec-Moczydłów oraz Wolka Zalewska-Moczydlów). Obszary te wymagają przede wszystkim monitorowania zmian w zagospodarowaniu przestrzennym, podjęcia kroków w celu objęcia ich ustaleniami planów miejscowych oraz ewentualnej weryfikacji polityki przestrzennej gminy w zakresie celowości utrzymania funkcji przyrodniczej. 
312 A. Pawłat-Zawrzykraj, K. Podawca

MS received May 2016

Authors' address:

Agata Pawłat-Zawrzykraj, Konrad Podawca

Katedra Geodezji i Planowanie Przestrzennego

Wydział Budownictwa i Inżynierii Środowiska

SGGW

ul. Nowoursynowska 159, 02-776 Warszawa

Poland

e-mail: agata_pawlat_zawrzykraj@sggw.pl

konrad_podawca@sggw.pl 